\title{
Tyrkiet: Islam sat \\ på standby
}

Af Lasse Ellegaard

Erdogans parti har mistet sit flertal i Nationalforsamlingen. Nogle tyrkere har fået nok af et tiårs snigende islamisering, andre har simpelthen fàet nok af Erdogan. Problemet er, at AKP har tabt den politiske uskyld, som partiet blev forbundet med i 2002.

Tørre tal lyver ikke, og Tyrkiets præsident, Recep Tayyip Erdogan, tabte 7. juni 2015 magtkampen med vælgerne om sin politiske fremtid. For valget til Nationalforsamlingen var også en folkeafstemning om udvidede magtbeføjelser til præsidentembedet. Og set fra det nyopførte palads i Ankara, hvor alene krystallysekronerne har kostet 35 millioner lira (90 mio. kr.), var den triste udgang, at et flertal sagde nej.

Med alle stemmer talt op er Erdogans parti, AKP (Adalet ve Kadinma Partisi - Retfærdigheds- og Udviklingspartiet), ganske vist stadig langt det største parti med godt 40 pct's tilslutning - men tilbagegangen på ni pct. i forhold til valget i 2011, da næsten 50 pct. stemte på det islamiske parti, var for stor til, at den uden videre kunne afskrives som forbigående metaltræthed i Erdogans traditionelle segment.

Budskabet er, at nogle har fået nok af et tiårs snigende islamisering af stort set alle hjørner af det tyrkiske samfund, mens andre har fået nok af Erdogan og blev hjemme på divanen. Men stemmeprocenten på 85 fortalte, at nye vælgere var aktiverede, primært de unge, der i stort tal stemte på HDP (Halk Demokratik Partisi - Folkets Demokratiske Parti). Med 12,9 pct. af stemmerne og 79 mandater passerede det kurdiske parti for første gang den spærregrænse på 10 pct., der blev sat i militærets forfatning fra 1982 med netop det formål at holde kurderne ude af parlamentet.

\section{Solkongen}

Det kurdiske partis fordobling af stemmetallet fra de seks-syv procent, der i mange år var normen, viste tillige, at hidtil politisk hjemløse blokke af alevi-muslimer, grønne venstre-radikale, armenske og græsk-ortodokse kristne, bøsser, lesbiske og andre outsidere omsider havde fundet et artikuleret alternativ i den unge kurdiske leder Selahattin Demirtas, der matchede Erdogans karisma.

Gennem 13 år havde Erdogan trynet de blegsottige og aldrende ledere af de to største oppositionspartier, CHP (Cumhurriyet Halk Partisi - Republikansk Folkeparti) og MHP (Millet Harekat Partisi - National Aktion Parti), med

Lasse Ellegaard, korrespondent i Istanbul, Jerusalem/Palæstina, Storbritannien og Libanon i perioden 1995-2014. Er i dag medarbejder på Dagbladet Information med Mellemøsten som speciale. Han har bl.a. udgivet bøgerne Med Gud i hælene (2007) og Det forrykte forår [2012]. 
eksponering af en ny national selvhævdelse, der på den ene side fremhævede den notorisk genrejste tyrkiske økonomi, på den anden side genkaldte en gloriøs imperial (islamisk) fortid. Erdogans slogan, 'Yeni Túrkiye' (Det Nye Tyrkiet) havde genklang i et vælgerhav, han for en tid kunne gå på.

For en tid. For kritikken af en stedse mere selvrådig leder voksede. Et pejlemærke er Facebook, hvor den dansktyrkiske socialdemokratiske politiker Yildiz Akdogan luftede sin skuffelse:

"Manden er den nye solkonge eller vil meget gerne være det. For tredeling af magten er VÆK i Tyrkiet, og staten tja... det er Erdogan. Trist, trist udvikling for det tyrkiske demokrati. Jeg havde ellers virkelig store forhåbninger om en reel mentalitetsændring i tyrkisk politik, da han kom tilbage i 2002, hvor han talte om reformer, nye tider mm. Men det er det samme igen dvs. stadig magtmisbrug, stadig klient-patronage-forhold og stadig ingen store fremskridt, hvad angår reelle demokratiske tiltag. Så ærgerligt for befolkningen, for minoriteterne i landet."

Akdogans følelsesudbrud ramte det tema, der fik mæle med HDP's valgsucces i juni: Den voksende liberale middelklasses skuffelse over erodering af det demokratiske nybrud, det var løftet med det islamisk-konservative partis valgsejr i 2002. Selvom ingen forventede et nyt, blankpoleret demokrati efter skandinavisk model, var der tillid til, at AKP betød mindre korrupt, nepotistisk og totalitær regeringsførelse end de foregående 80 års kemalistiske regimer.

Den forventning blev ikke indfriet i AKP's tre valgperioder er korruption og totalitære tendenser tiltaget, og er nu langt større og i mere 'professionelt' format, end under de sekulære kemalistiske koalitions-regeringer.
Frem til juni 2015 kunne man med Yildiz Akdogan tale om Tyrkiet som et 'demokratur' med islamiske under- og overtoner og regeret af en enkelt mand: Erdogan. Nu, hvor han for første gang har lidt de facto nederlag som politisk leder, er der grund til at analysere hans periodes indvirkning på det land, der i dag er verdens 17. største økonomi, men kun nummer 64 på Transparency Internationals korruptionsindeks for 175 lande.

\section{To slags islamisme}

Tyrkiske muslimer knytter traditionelt an til hanafi-skolen, den mest moderate af sunni-islams fire hovedskoler og de osmanniske sultaners foretrukne teologi, og sådan vedblev det med at være også efter den sekulære kemalistiske republiks formelle adskillelse af religion og stat - islam var nu folks private anliggende og med kalifatets nedlæggelse i 1924 uden symbolske eller samfundsmæssige funktioner. Formelt. For islam forblev en vejledende om end underjordisk politisk faktor uden for den kemalistiske elite - og med tiden også inden i den.

Efter Anden Verdenskrig udvikledes to versioner af politisk islam, den ene ofte camoufleret med neutrale partinavne, men med indbygget islamisk appel som eksempelvis DP (Demokratik Partisi) i 1950 og mere åbenlyst i 1970 med Necmettin Erbakans MNP (Milli Nizam Partisi - National Orden Parti), det første af flere islamistiske partier under hans ledelse.

Erbakan var discipel af Mehmet Zahid Kotku, en sufi-imam tilknyttet den verdensomspændende Naqshabendiorden, der leverede det teologiske underlag til den særlige tyrkiske islamisme, som Erbakan satte i system med kadredisciplin efter leninistisk model, og som 
sigter på at erobre statens institutioner gennem direkte politisk handling, altså ovenfra og i modsætning til islamismens andet hovedspor i tyrkisk politik Hizmet (Tjenende), der ligeledes søger at erobre staten, men nedefra med eksemplets magt som løftestang.

Hizmet, der også kendes som 'nursisterne', 'gülenisterne' eller Nur Cemaati (Lysets Fællesskab), har rødder i den tænkning, den kurdiske imam Said Nursi (1877-1960) lancerede i begyndelsen af 1900-tallet, og som hurtigt fik betydelig indflydelse. Han skrev et samlet værk Risale-i Nur, der i 24 bind søger at forene konkret viden(skab) med religiøs eskatologi.

Said Nursi var - som i øvrigt de mest lærde shiitiske ayatollaher - indædt modstander af direkte deltagelse i politik, og advarede i sine skrifter mod dannelse af religiøse partier (han huskes især for sit afslag til Mustafa Kemal Atatürks tilbud om at gøre ham til minister for religiøse anliggender). Tværtimod påbød han sine tilhængere at påvirke samfundet via deres meritters eksempel, primært ved uddannelse og opofrelse til 'det fælles bedste'.

Dette påbud blev sat i organisatorisk system af Nursis fremmeste discipel, den nu 74-årige Fetullah Gülen, en imam, der forlod sin bekvemme statsansættelse ved en moské i Izmir i 1981 for at organisere Nursis tænkning i et netværk, der i dag har millioner af tilhængere, egne læreanstalter, massemedier, forlag og finansielle institutioner med internationale filialer i Sydasien, Afrika, USA og såmænd i Danmark.

Akkurat som sin mentor blev Gülen mistænkt for undergravende aktiviteter mod den tyrkiske sekulære stat, hvorfor han emigrerede til USA i 1999. I Tyrkiet blev han tiltalt og dømt in absentia i 2000, men frikendt i 2008 ved en appelret ef- ter intervention af Erdogan, der så gülenisterne som en politisk forbundsfælle trods de ideologiske og teologiske forskelle mellem hans parti og Hizmetbevægelsen.

\section{Erdogan overtager kontrollen}

Som skolede og veluddannede blev gülenisterne fra AKP-periodens begyndelse i 2002 promoveret i retsvæsen og politi, og var således ved hånden, da Erdogan $\mathrm{i}$ 2007 iværksatte en større udrensning af sekulære kemalister i militæret, administrationen og medierne. Samme år havde AKP annekteret kemalisternes sidste bastion, præsidentembedet, hvilket udløste militærets fejlslagne 'internet-kup', et sidste forkølet forsøg på at bremse islamisternes politiske damptromle.

Erdogan svar var et valg, som AKP vandt stort, og i 2008 blev partiet frikendt ved forfatningsdomstolen for en anklage om 'undergravende og islamistisk propaganda'.

I 2009 blev den militære generalstab udskiftet, hvilket eliminerede militærets sidste rest af modstand mod den igangværende islamisering, og i 2010 blev chef-imamen for Direktoratet for Religi$ø$ se Anliggender udskiftet i utide med en Erdogan-proselyt, Mehmet Görmez, der blev voldsomt eksponeret i offentligheden som deltager i officielle seancer, der tidligere var forbeholdt de formelt sekulære politikere. Erdogan kontrollerede nu alle aspekter af staten.

AKP's og Hizmets tætte alliance holdt trods ideologiske modsætninger og magtkampe til 2009, hvor de første revner viste sig. Den brød endeligt sammen efter valget i 2011 med hver anden vælgers kryds ved AKP. Erdogan havde ikke længere brug for gülenisternes støtte og så nu Hizmet som en stigende politisk trussel. Hvilket også var tilfældet: I hvert fald gik 
Fetullah Gülen til modangreb i 2012, da han i et tv-interview i USA skarpt kritiserede Erdogan og AKP for at forvride demokratiet i sin stedse større selvrådighed.

Det var en krigserklæring, og tro mod sit temperament har Erdogan siden tordnet mod gülenisterne som en farlig femte kolonne, en 'parallel stat', der kun pønser på at omstyrte ikke alene ham, men det demokratiske system.

Gülenisternes svar er, at AKP ikke er et religiøst parti, men en mafia med henvisning til politiets aktion i december 2013, da 53 personer blev anholdt for korruption i megaformat med offentlige licitationer, omgåelse af eksportforbud til det sanktionsramte Iran og hvidvaskning af enorme sorte beløb.

Affæren fik fire ministre til at gå og havde snore til Erdogans nære familie, nemlig sønnen Bilal. Den blev tolket som Hizmets hævnakt efter en regeringsbeslutning om at nedlægge de såkaldte imam hatip-skoler (universitetsforberedelseskurser), som Hizmet drev som en af flere økonomisk givtige aktiviteter.

\section{Erdogans hævn}

Erdogans gengældelse kom i december 2014, da politiet - efter at regeringen havde udrenset de politifolk og anklagere, der havde gennemført korruptionsefterforskningen i 2013 - skred til aktion mod tv-stationen Samanyolu og Tyrkiets største avis, Zaman, begge drevet af Hizmet-netværket, og anholdt begge mediechefer og et antal medarbejdere.

En 'muldvarp' med pseudonymet Fuat Avni, der menes at have sæde i enten AKP-ledelsen, regeringen eller efterretningstjenesten, og som jævnligt tweeter afsløringer om Erdogans og AKP's mere dunkle aktiviteter, tweetede efter politiaktionen mod avisen og tv-kanalen, at nye anholdelser var undervejs.
Blandt dem, der angiveligt stod på listen for kommende interneringer, var min gode bekendte, Kerim Balci, redaktøren af Zaman-koncernens engelsksprogede tidsskrift Turkish Review og en ledende skikkelse i Hizmet. Så da jeg i januar drak kaffe med Balci i Zamans stål- og glaspalads i Istanbul, lod jeg en bemærkning falde om hans navn på AKP’s sorte liste.

"Ja, jeg står endda øverst", svarede han med et bredt smil.

"Men det er vel logisk, eftersom politiets Hizmet-aktivister er ude efter Erdogan og hans familie", sagde jeg.

"Det er faktisk ikke vores folk", svarede Balci. "Korruptionssagen blev indledt lang tid før AKP besluttede at lukke imam hatip-skolerne, men når de to sager synes at hænge sammen, skyldes det alene, at regeringsbeslutningen om lukning først blev offentliggjort 13. december 2013, og operationen mod de korruptionssigtede fandt sted 17. og 25. december. Men efterforskningen af sagerne var indledt halvandet år før efter en korrespondence mellem finansministeriet og Istanbuls chefanklager, der blev opfordret til at se nærmere på en række uregelmæssigheder, som ministeriet var gjort opmærksom på. I april 2013 fik Hakan Fidan, chef for MIT (efterretningstjenesten), nys om efterforskningen, bl.a. om at Erdogans søn var blandt de involverede tillige med fire ministre. Fidan informerede Erdogan, og først derefter besluttede regeringen at lukke skolerne - overbevist om, at Hizmet stod bag sagen mod de korruptionssigtede, ville Erdogan sikre sig et forhandlingskort: Hvis politi og anklagemyndighed henlagde korruptionssagen, ville han lade skolerne i fred."

Hizmet svarede, at bevægelsen ikke havde noget med korruptionssagen at gøre, og at de ikke kunne påvirke processen, og selv hvis de kunne, ville de ikke. 
Da landsfader Mustafa Kemal Atatürk [1881-1938] blev spurgt, om hvorfor modernisering alene betød sekulær, europæisk civilisation, svarede han: Findes der nogen anden? Hattedirektivet fra 1925 er typisk for Atatürks projekt: han forbød turban og fez, idet borgere i en progressiv republik bar Borsalino-hat, kasket eller baret.

Også chefanklageren blev sat under direkte pres, og har siden fortalt om adskillige henvendelser med 'gode råd' om at droppe sagen.

Kerim Balci erkender, at det var en fejl, at Hizmet ikke gik offentligt ud med Erdogans pressionsforsøg.

"Vi havde jo ikke noget imod, at folk troede, vi stod bag oprydningen i korruptionsskandalen, for vi støttede den fuldt ud og gned os i hænderne, men det var en fejl - vi skulle have lagt afstand til den affære", sagde han, og tilføjede:

"Vi har lavet flere fejl. Det var også en fejl, at vi deltog i AKP's udrensning af sekulære modstandere i de kontroversielle skandalesager 'Ergenekon' og 'Balyoz' (Forhammer). Vores folk i politi og anklagemyndighed deltog i anholdelser af de journalister og officerer, der blev hentet klokken fire om morgenen. Og vi elskede det og sagde ikke nej, men var ukritiske over for overgrebene, også i vores medier. For i lighed med vores daværende venner i AKP, var også vi paranoide over for muligheden af ny militær indblanding i politik - men det var forkert af os at deltage, for vi vidste også, at de sager havde ringe juridisk kvalitet."

At gülenisterne bevidst så den anden vej, også da det blev åbenlyst, at Ergenekon- og Balyoz-komplekset byggede på halve beviser og fabrikerede anklager af 'ringe juridisk kvalitet', som Kertrim Balci udtrykker det, gjorde ikke kun Hizmet til medskyldig i justitsmord, men skabte også en myte om, at gülenisterne stod bag enhver opsigtsvækkende politiaktion - og altså også bag korruptionsafsløringerne i december 2013 med de 53 anholdte og et samlet kriminelt beløb på frapperende 13 milliarder dollars. Men ifølge Kerim Balci havde den chefanklager i Istanbul, der ledede undersøgelsen, ingen forbindelse til Hizmet, men var tværtimod kendt for tætte kontakter til nationalistiske kredse.

\section{Militære kup}

Historisk er den udgave af politisk islam, Erdogan og AKP repræsenterer, produkter af de tyrkiske militærkup, primært kuppet i 1980, det tredje efter etablering af flerpartisystemet i $1950 \mathrm{i}$ anledning af landets indlemmelse i NATO.

Adnan Menderes, en deputeret for CHP, den gang det eneste parti i Nationalforsamlingen, blev betroet dannelsen af DP (Demokratik Partisi), der på forhånd var udset til en sekundær, nærmest pro forma rolle. Hvad kemalisterne ikke forudså var, at muslimske bønder og arbejdere sukkede efter et alternativ til de sekulære, arrogante magthavere og stemte DP ind i parlamentet med solidt flertal.

Menderes regerede frem til 1960, hvor han efter afsluttet Marshall-hjælp og ophør af yderligere amerikanske kreditter søgte økonomisk støtte i Sovjetunionen efter samme model, som Egyptens Nasser havde praktiseret. En gruppe yngre officerer med fascisten, den senere nationalist-leder Alparslan Türkes ispidsen, iværksatte et kup og hængte Menderes og hans finansminister efter en summarisk rettergang. Andet militærkup kom i 1971 mod Menderes' efterfølger i DP, Süleyman Demirel, og havde til formål at sætte stopper for blodige fejder mellem venstreradikale, højrenationalister og militante islamister, hvilket mislykkedes. 
I 1980, da venstre- og højre-radikale havde bragt landet ud i veritabel borgerkrig, greb militæret ind for tredje gang mod en vaklende koalitionsregering, igen med Süleyman Demirel i spidsen og med Necmettin Erbakans islamister i rollen som støtteparti. Denne gang brugte soldaterne skarp lud - 50 blev henrettet, tusinder blev fængslet, titusinder tortureret, og atter andre forsvandt sporløst. De politiske partier blev forbudt, og kupgeneralen, Kenan Evren, udnævnte sig selv til præsident med en apolitisk bureaukrat, Turgut Özal, som premierminister.

Özal viste sig at være langtfra apolitisk. Han strømlinede den tyrkiske administration (han indførte computeren), iværksatte økonomiske og sociale reformer, tillod dannelsen af 'parallelle' politiske partier og var primus motor i en ny forfatning, der fra 1982 genetablerede formelt demokrati.

Özal tillod de gamle politikeres genkomst ved valget i 1987, som han i øvrigt vandt overlegent, og i 1989 overtog han præsidentposten efter Kenan Evren. Og vigtigst: de tyrkiske islamister blev rehabiliteret med øgede bevillinger til moské -byggeri og større andel i økonomien i form af erhvervsvirksomheder, forsikringsselskaber og banker.

Veteranen Necmettin Erbakan fik politisk råderum som modvægt til både socialdemokrater, radikale venstreorienterede og MHP's 'grå ulve', der til denne dag udgør den største sikkerhedsrisiko ved fodboldkampe.

\section{Atatuirks sekularisme}

At militærkuppet i 1980 satte skub i politisk islam, lå ikke i kortene. Republikken blev etableret i 1921 på dogmet om en sekulær, nationalistisk enhedsstat - partier af religiøs eller etnisk orientering var følgelig forfatningsstridige. Da landsfader
Mustafa Kemal Atatürk (1881-1938) blev spurgt, om hvorfor modernisering alene betød sekulær, europæisk civilisation, svarede han: Findes der nogen anden?

Hattedirektivet fra 1925 er typisk for Atatürks projekt: han forbød turban og fez, idet borgere i en progressiv republik bar Borsalino-hat, kasket eller baret. Han nedlagde kalifatet i Istanbul i 1924, erstattede det arabiske alfabet med det latinske i 1926 og gjorde staten til den allestedsnærværende autoritet, beskyttet af soldaterne og regeret af en elite af sekulære bureaukrater.

De 81 provinsguvernører blev udnævint centralt, et statsligt gendarmeri fungerede parallelt med de lokale politistyrker. Lærere og sundhedspersonale blev efter endt uddannelse sendt ud til samfundstjeneste i provinserne, og en stram kommandoøkonomi kontrollerede de (militært) vitale erhvervssektorer, banker, minedrift, olie og sværindustri, men privat markedsøkonomi var tilladt $\mathrm{i}$ handel og mindre industrier. Infrastruktur, anlægsarbejder og allokering af økonomi blev dikteret fra Ankara i et system, der til denne dag kan spores i dele af samfundsøkonomien.

\section{Erbakans islamiske base}

Erbakan havde i modsætning til andre partiledere, der blev ramt af forbudet mod politiske partier, bevaret kontrollen med sin base i de skiftende islamistpartier, han ledede, og som rutinemæssigt var blevet forbudt ved den tyrkiske forfatningsdomstol - i øvrigt i lighed med de kurdiske partier med dom for forfatningsbrud.

Hvor der var to socialdemokratier, to liberale partier, to konservative, etc. som følge af kuppets forbud, kunne Erbakan genindtræde som leder af sit gamle parti, omdøbt til Refah (Velfærd) - og base for de unge udbrydere, der i 2001 dannede AKP.

Den politiske åbning mod islamisterne 


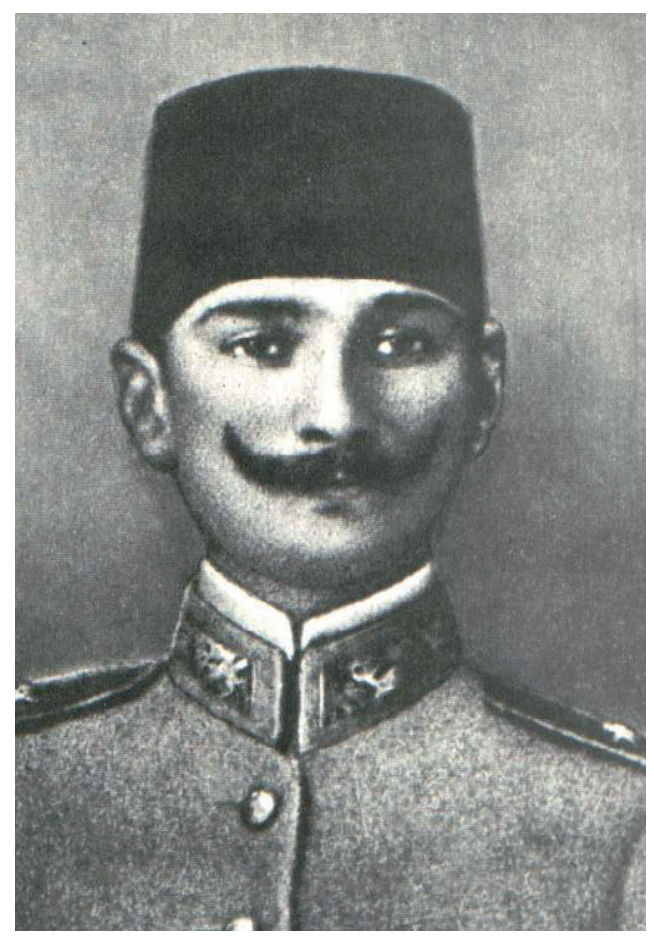

FOTO: Via Wiki Media, 2015

som modvægt mod venstrefløjen fik gennemslagskraft med Turgut Özals delvise $ø$ konomiske reformer, der medførte ophør af det statslige mediemonopol.

Pludselig var islamisterne nationalt synlige på privatejede, islamisk finansierede tv- og radio-kanaler, og Erbakan kunne eksponere sit parti, Refah (Velfærd), med et politisk program, der var ligeligt socialt og religiøst med støtte af bønder, det andelsbaserede erhvervsliv i det centrale Anatoliens 'koranbælte', hvor byer som Konya, Kayseri og Amasya ekspanderede, og ikke mindst i i de storby-ghettoer, der blev beboet af 'afvandrere' fra land til by op gennem 1970'erne og 80'erne.

Ved lokalvalgene i 1994 vandt Refah i 12 pct. af kommunerne, herunder Ankara og ikke mindst Istanbul, hvor den unge islamiske aktivist og tidligere halvprofessionelle fodboldspiller Recep Tayyip Erdogan blev overborgmester.
Fez'en var blevet påbudt som mandlig hovedbeklædning i Osmannerriget i 1832, men blev i 1925 forbudt, da Atatürk med hattedirektivet - der forbød turban og fez - ønskede at lægge afstand til den osmanniske kultur. Han mente, at borgere i en progressiv republik bar Borsalino-hat, kasket eller baret. På billedet er det en ung Mustafa Kemal Atatürk, fotograferet i Damascus i 1906, der selv bærer den traditionelle hovedbeklædning.

Parlamentsvalget 24. december 1995 gjorde Refah til Tyrkiets største parti med godt 21 pct. af stemmerne, og Erbakan dannede efter måneders prangen $\mathrm{i}$ korridorerne regering med den afgående premierminister Tansu Çillers sekulære DYP (Dogrul Yolu Partisi - Den Rette Vejs Parti) nu med Erbakan som første islamiske premierminister og Tansu Çiller som udenrigsminister.

Det gik selvfølgelig ikke - i februar 1997 vedtog det militært dominerede nationale sikkerhedsråd en bandbulle mod Erbakan og Refah, der i juni førte til hans fald ved det såkaldt 'postmoderne kup' - DYPparlamentarikere blev simpelthen bestukket, truet eller intimideret til at desertere fra det flertal, der udgjorde regeringens parlamentariske underlag. Året efter blev Refah forbudt efter en forfatningsdomstolsprocedure, og Erbakan blev fradømt retten til politisk virksomhed i 10 år. 
Refah genopstod som Fazilet (Dydernes Parti) med Erbakan som dukkefører, men også Fazilet blev forbudt, og i 2001 erkendte Erdogan og partiets anden unge komet, Abdullah Gül (der havde stillet op som formand for Fazilet og blev slået knebent af et medlem af den gamle garde), at Erbakans æra var forbi. Sammen med andre yngre løver som den senere parlamentsformand Bülent Arinc og det unge stortalent Ali Babacan brød de med deres mentor og dannede AKP.

Det nye parti markerede adskillelsen fra Erbakans traditionelt antivestlige kurs med en u-vending på 180 grader i holdningen til tyrkisk EU-medlemskab, ligesom det nedtonede det religiøse aspekt til neutralt 'værdibaseret' og kaldte sig konservativt i den kemalistiske tradition.

\section{Sammenbrud og reformer}

Fornyelsen gav pote - vælgerne var trætte af de gamle partiers vanedannende korruption, den galopperende inflation og statens og militærets inkompetence, da en jordskælvskatastrofe indtraf i 1999. Og da en økonomisk krise i 2001 halverede den tyrkiske liras værdi på en enkelt nat efter et heftigt skænderi mellem præsidenten, Ahmet Sezer, og premierministeren, Bülent Ecevit, i Det Nationale Sikkerhedsråd, var sammenbruddet uundgåeligt.

Bataljen drejede sig om den manglende kontrol med finanssektoren efter en stribe bankkrak, og den førte til, at IMF overtog styringen af den økonomiske politik som modydelse for substantielle lån. Da et nyvalg blev udskrevet i utide til november 2002, stod AKP klar som tillokkende alternativ til roderiet.

De 'nye' islamister gik straks i gang, og med hjælp fra bl.a. den næstkommanderende på den danske ambassade i Ankara - Danmark havde EU-formandskabet i første halvdel af 2002 - blev der bundet sløjfer på en stribe reformpakker, der alle var målrettet til genopretning af økonomien; og accept af Europa-Kommissionens årlige 'karaktergivning' banede vej for den tyrkiske ansøgning om fuldt medlemskab.

Pakkerne omfattede privatisering af offentlige virksomheder, demokratisering af retssystemet, ny familelovgivning, neutralisering af militærets politiske dominans, ytrings- og pressefrihed, udvidet ret til at etablere politiske partier, en moderne arbejdsmarkedpolitik, liberal markedsøkonomi og ligestilling mellem kønnene - hvor det dog kneb en smule, bl.a. blev et forslag om at straffe utroskab med fængsel trukket tilbage.

Også på det ømskindede politiske område, det kurdiske spørgsmål, var AKP åben for løsninger, der brød med den hidtidige eksklusion af kurdisk kultur som farlig for enhedsstaten.

Valgsejren rensede ud i partifaunaen, idet kun AKP og Atatürks gamle republikanske CHP kom i parlamentet med 358 pladser til AKP, 178 til CHP plus ni 'uafhængige’ kurdiske løsgængere. Reformpakkerne blev vedtaget $i$ lempeligt tempo, der ikke udfordrede det vagtsomme militær, stadig med flertal i Det Nationale Sikkerhedsråd som 'rådgivende' overregering.

AKP undlod i første omgang at antaste militæret direkte, men indledte en kulturkamp med krav om fjernelse af forbudet mod kvinders hovedtørklæder i institutioner og i uddannelsessystemet, ligesom en gradvis, men effektiv udskiftning af embedsmænd i sikkerhedstjenester, politi og statsbureaukrati blev indledt.

En vigtig medspiller i den proces var som nævnt Hizmet, hvis glatbarberede moderate islamisme (ikke ulig Det Muslimske Broderskabs oprindelige program i Egypten), var velegnet til infiltration af statslige institutioner indefra som en slags 
Strategien har hele tiden været at erobre den sekulære stat indefra og omdanne den til en islamisk domineret republik, der legitimerer rollen som muslimsk regional stormagt, som masserer de sunni-muslimske arabiske massers politiske aspirationer og tager parti for disses krav om politisk råderum.

hjælpetropper i AKP’s uerklærede krig mod den sekulære stat.

\section{Et skridt frem - og to tilbage}

I januar 2005 blev Tyrkiet anerkendt som ansøger til fuldt medlemskab af EU. Reformpakkerne havde virket efter hensigten, og AKP kunne begynde en egentlig demokratiseringsproces med EU som løftestang: Eliminering af militærets politiske rolle og forhandling med kurderne om en række kulturelle rettigheder, bl.a. øget ytringsfrihed og ret til at undervise på kurdisk. PKK, der er på EU’s og USA's terrorlister, erklærede flere ensidige våbenhviler, og et begyndende retsopgør om statslige overgreb i det sydøstlige Tyrkiet blev indledt.

Forholdet til kurderne i Nordirak blev normaliseret som optakt til økonomisk eksport-ekspansion, og en opblødning af Tyrkiets politik på Cypern resulterede i Annan-planen i 2004, hvor den tyrkiske minoritet stemte for en genforening som så blev afvist af den græske side. Det vakte vrede i Ankara, at EU, trods løfter om det modsatte, indlemmede den græske del af øen i fællesskabet.

En møntreform blev iværksat sideløbende med en stram finanspolitik, der nedbragte inflationen til encifrede procenter, beskæftigelsen og konkurrenceevnen steg, og sundheds- og socialvæsen blev forbedret. Om end det aldrig er blevet perfekt, kan almindelige mennesker i det mindste se en læge.

Men gradvis gled EU-ambitionen i baggrunden, og en begyndende islamisering af samfundet blev indledt, i begyndelsen med et markant nybrud i udenrigspoli- tikken, formuleret af Erdogans rådgiver og senere udenrigsminister, Ahmet Davutoglu, der efterfulgte sin chef som premierminister og leder af AKP. Han havde i en bog genoplivet Necmettin Erbakans idé fra 1970'erne om et mellemøstligt fællesmarked med Tyrkiet i en ledende økonomisk og politisk rolle, hvilket ville føre til mindre afhængighed af Europa og USA.

Med den endelige eliminering af militæret som politisk faktor indledte AKP - som nævnt ivrigt bistået af Fetullah Gülens Hizmet-kadrer - en arrestationsbølge af officerer, bureaukrater og journalister, der blev anklaget for at forberede kup mod regeringen i den angivelige hensigt at føre Tyrkiet 'tilbage til kemalismen'.

Noget var der om snakken: Pensionerede officerer havde lagre af våben og syslede med blueprints for et kup, men Erdogan benyttede den bagatelagtige sag til at fængsle modstandere i hundredevis - heraf flere end 200 officerer, bl.a. tidligere generalstabschefer, der intet kendskab havde til kupmagerne. Fængselsdomme blev afsagt i skueprocesser, der bevirkede, at moderate og liberale grupperinger, der hidtil havde støttet AKP som det mere spiselige alternativ til den kemalistiske stat, trak deres støtte.

Men da havde AKP konsolideret sin magt, inklusive i hovedparten af de toneangivende massemedier, og havde udenrigspolitisk vendt sig fra EU - de sidste fem år er kun ét kapitel åbnet i den formelle forhandlingsprocedure. Strategien har hele tiden, kan man se nu, været at erobre den sekulære stat indefra og omdanne den til en islamisk domineret republik, der legitimerer rollen som muslimsk 
regional stormagt, som masserer de sunni-muslimske arabiske massers politiske aspirationer og tager parti for disses krav om politisk råderum.

I den proces er bruddet med Israel et afgørende element såvel som bruddet med Bashar al-Assads Syrien. Af begge grunde vakler Tyrkiets NATO-alliance, hvilket har vist sig i afvisningen af at lade amerikanske fly angribe Islamisk Stat fra Incerlik-basen i det sydlige Tyrkiet, ligesom tyrkernes politik i Syrien er på kollisionskurs med USA's i krigen mod Islamisk Stat og i spørgsmålet om det syriske regimes overlevelse.

Tyrkiet er fast besluttet på at vælte Bashar al-Assad, hvor Vesten i stigende grad kalkulerer med hans overlevelse for at undgå en truende balkanisering ved at sikre det syriske statsapparats overlevelse.

Forklaringen er enkel: Tyrkerne er sunnimuslimer, al-Assad er alawit, en shia-sekt. Vesten er som pragmatisk sekulær spiller interesseret i stabilitet uanset Assads religion; for AKP er der tale om både et eskatologisk opgør med en vantro antikrist og realpolitik gående ud på at inddæmme og helst eliminere kurdernes ambitioner om selvstændighed i Syrien-Irak, der ikke kan undgå at smitte af på kurderne i Tyrkiet.

\section{Individualismen og islamismen}

Men det virkelige problem er tabet af den politiske uskyld, AKP blev forbundet med i 2002, og som for mange er afløst af det mismod, Yildiz Akdogan udtrykte på sin Facebook-væg i 2014.

To begivenheder illustrerer dette mismod: Protesterne i juni 2013 mod ekspropriering af en grøn plet, Gezi Park, der er udset til butikscenter i osmannisk stil som kopi af den imperiale kaserne, der lå på stedet tidligere.

Demonstrationerne, der begyndte som fredelige miljøprotester og bredte sig til de tyrkiske storbyer, var først og sidst vendt mod Erdogans demokratur-tendens med invasion af privatsfæren, hvor han gav gode råd om, hvordan tyrkerne bør føre sig frem i deres soveværelser, så republikken producerer flere børn.

Men modsætningerne går dybere - de handler om individets behov over for kollektivets krav, ikke kun om sekulære værdier over for islamisk tankegang, men om republikkens selvforståelse, knæsat under kemalismen, hvor individet er til for staten, ikke omvendt.

Problemet er bare, at halvdelen af tyrkerne bl.a. som en følge af AKP's reformer i begyndelsen af 00'erne nu hylder en 'vestlig' individualisme, mens den anden halvdel er forblevet i det islamiske, 'kollektive', eller om man vil 'autoritetstro' verdensbillede, der var gældende i det 20. århundrede.

Erdogan tilsatte en neo-osmannisk vision til denne tankegang, der satte Koranens værdiskala over individets behov. Og han gjorde det med henvisning til sit flertal blandt vælgerne - at det var hans legitime billet til den fuldkomne magt. Han blev - i lighed med andre muslimske magthavere som fx præsident Mohammed Morsi og hans efterfølger, Abdel Fattah el-Sisi, i Egypten - ekskluderende frem for inkluderende.

Det gik godt, så længe økonomien gik godt med vækstrater i østasiatisk format; men nu, hvor den er fladet ud med en inflation vippende omkring de frygtede to cifre, er islamisternes magi blegnet. Årsagen er dels efterklangen af finanskrisen, dels at det arabiske forår kom i vejen for ekspansion i den arabiske verden og endelig, at Tyrkiet har været tvunget til at følge de amerikanske sanktioner mod Teheran.

Men kun delvist - elementer i korruptionsskandalen december 2013, der eks- 
ponerede Erdogans fravær af moralsk bonitet, var direkte udløbere af sanktionerne. Tyrkiet betalte energi fra Iran med guldbarrer, da normale bankprocesser var suspenderede som følge af sanktionerne, hvilket medførte et sindrigt system af bestikkelser og hvidvask af pengebeløb, udført af nøglepersoner i finanstilsyn, embedsværk og regering.

Samtidig afsløredes fifleri med offentlige licitationer, der udelukkende gik til AKP's støtter med returkommissioner i milliard-klassen - ifølge Kerim Balci blev licitationsloven ændret 156 gange for at imødekomme skiftende tilbudsgiveres interesser. Resultatet blev, at de såkaldt 'varme investeringer', altså kortvarige indlån fra udlandet, blev trukket ud af tyrkisk økonomi, hvorefter bankerne ikke kunne forstrække Erdogan med de lån, han behøvede for at gennemføre sine ambitiøse projekter, herunder en tunnel under Bosporus og en ny lufthavn.

Og nu har han mistet sit absolutte flertal i Nationalforsamlingen. Det store spørgsmål er, om han er blevet klog af skade. 
